\title{
Association of vitamin D insufficiency and low physical activity with fatigue, headaches and psychological distress in college students, North-Mediterranean Croatia - a pilot study
}

Tatjana Kehler ${ }^{1}$, Tanja Grubić Kezele², Ariana Fužinac-Smojver ${ }^{3}$, Tamara Kauzlarić-Živković1

The aim of the study was to investigate serum vitamin D level in undergraduate students of health studies and its relationship with the frequency of vitamin D rich food consumption, sun exposure, study-related fatigue, headache and psychopathological status, and the relationship of the latter three parameters with the type of physical activity. A blood level of 25-hydroxyvitamin D (25(OH)D), Migraine Disability Assessment (MIDAS), Pediatric Quality of Life Inventory Multidimensional Fatigue Scale, Clinical Outcomes in Routine Evaluation-Outcome Measure (CORE-OM), nutrition and physical activity were surveyed in randomly chosen students. Study results showed that $49 \%$ of students had 25(OH)D insufficiency/deficiency. The MIDAS values were higher in the insufficient/ deficient group ( $p=0.035)$ and were associated with hours of weekly cardio exercises $(r=-0.48, p=0.031)$. CORE-OM and total fatigue correlated with $25(\mathrm{OH}) \mathrm{D}(r=-0.59, p=0.024 ; r=0.51, p=0.023)$. Students with sufficient $25(\mathrm{OH}) \mathrm{D}$ had a significantly higher vitamin $\mathrm{D}$ intake by consuming sardines in their monthly nutrition $(p=0.048)$. 25(OH)D correlated with the amount of monthly consumed sardines ( $r=0.59, p=0.006)$ in general. Our results provide initial evidence that an appropriate lifestyle along with proper physical activity, especially cardio exercise, and vitamin D rich nutrition is important to reduce fatigue, headaches and psychological distress.

Keywords: DEPRESSION; FATIGUE; HEADACHE; EXERCISE; VITAMIN D

\section{INTRODUCTION}

Mental health and well-being of students is particularly important, as some studies have identified that students were more likely to experience symptoms of mental ill-health, especially anxiety and depression as compared to other young people (1), which is caused by their concerns about their studies. Worryingly, one study has reported that $60 \%$ of undergraduate students had elevated levels of anxiety and depression (2). Furthermore, many university students experience high levels of study-related headaches and fatigue as concomitant symptoms.

Besides the study-related stress and concomitant depression, anxiety, headaches and fatigue, inappropriate nutrition and low level of physical activity affect students' health and academic success. Adolescents including young adults, especially undergraduate students, are considered as a risk group for malnutrition because of their increasing needs of

\footnotetext{
1 Department of Physical Medicine and Rehabilitation,

Thalassotherapia Opatija, Opatija, Croatia

${ }^{2}$ Department of Physiology, Immunology and Pathophysiology,

University of Rijeka Faculty of Medicine; Department of Clinical

Microbiology, Clinical Hospital Center Rijeka, Rijeka, Croatia

'Department of Basic Medical Sciences, University of Rijeka,

Faculty of Health Studies, Rijeka, Croatia
}

\section{Correspondence to:}

Tanja Grubić Kezele, Ph.D., M.D., Department of Physiology, Immunology and Pathophysiology, University of Rijeka Faculty of Medicine, Rijeka,

Department of Clinical Microbiology, Clinical Hospital Center Rijeka,

Rijeka, Croatia,E-mail: tanja.grubic@medri.uniri.hr

Primljeno/Received: 09. 06. 2020., Prihvaćeno/Accepted: 24. 10. 2020. 
nutrients and energy for adequate growth and development that vary with age, including intense cognitive work (3). Accordingly, vitamin D deficiency is specifically frequent and has been associated with fatigue and other non-specific symptoms including headache, musculoskeletal pain and weakness, depression, and impaired cognitive performance (4). The main sources of vitamin D are food intake and subcutaneous skin synthesis under UV light (290-315 nm) exposure. However, exposure to sunlight may be critical in certain geographical areas and thus cannot compensate for inadequate nutritional intake (3).

Vitamin D deficiency is incredibly common and most people are unaware of it. That is because the symptoms are often subtle and non-specific, meaning that it is hard to know if they are caused by low vitamin D levels or something else. Subclinical vitamin D deficiency could remain undetected as it is not routinely screened for in this population group. Vitamin D plays various roles in normal brain physiology, which are responsible for feelings of wellbeing (5-7).

In addition, physical activity can have beneficial effects on mental health (8) and often concomitant fatigue (9) and headaches (10). The primary aim of the current study was to investigate undergraduate student physical activity habits and their relationship with study-related fatigue (cognitive fatigue, overall fatigue, and need for recovery), headache frequency and severity, and psychopathological status. Furthermore, we wanted to examine their serum $25(\mathrm{OH}) \mathrm{D}$ level as the main circulating vitamin D metabolite. It is proposed as the best indicator of vitamin D status that represents the amount taken by diet and subcutaneous synthesis (3), and also its relationship with the frequency of vitamin $D$ rich food consumption, study-related fatigue, headache severity, and psychopathological status.

\section{SUBJECTS AND METHODS}

\section{Participants, recruitment and study design}

This cross-sectional pilot study assessed the association of blood 25(OH)D status, consumption frequency of vitamin D rich food, sun exposure and study-related fatigue, headache frequency and severity, and psychopathological status in a sample of undergraduate students divided into two groups of 25(OH)D insufficient/deficient and 25(OH)D sufficient subjects. Furthermore, the aim was to examine the relationship of the latter three health disorders (fatigue, headache and psychopathological status) with student habits regarding the type of physical activity they had in the last two months.

Sixty-two undergraduate students were randomly recruited at the beginning of September at the Faculty of Health
Studies, University of Rijeka, in the northern part of Mediterranean Croatia. Inclusion criteria were students aged 18-24 years of both sexes, self-reporting their skin colour as white and no vitamin $D$ supplementation in the last six months. Students were informed about the study character and explained their participation in the period of two months before filling out the questionnaire and collecting blood samples (beginning of September). The inclusion criteria were met by 58 students, who were instructed to keep a journal about their everyday nutrition and physical activity, presence of headaches and number of days headache affected their activities (home, school, and social activities, work), presence of fatigue and its impact on daily physical and cognitive activities, and the need for rest. All students were volunteers and signed the informed consent form. The research was approved by the Research Ethics Committee of the Faculty of Health Studies (ID: 003-01/19-01/04).

A single well-trained researcher (physician) collected all demographic data (sex, age, body mass index /BMI/) and conducted the first interview about the possible presence of mental or other acute and chronic illness and identification of the skin type according to the Fitzpatrick scale (11). All 58 interviewed students stated they had no diagnosed mental or other acute and chronic illness and were not using vitamin D supplementation or medications.

After 52 students properly completed the self-reported questionnaire about headache severity, fatigue, psychological status and survey about their nutrition habits/frequency and consumption of vitamin $D$ rich food in the last two months (end of October), they underwent blood sampling in the Opatija Thalossotherapia laboratory for $25(\mathrm{OH}) \mathrm{D}$ and other routine blood measurements. Independent researchers were collecting data from the questionnaire. Students with anaemia, infection/inflammation, or any type of chronic and autoimmune disease were excluded from the study. After the sample size calculation, 45 students were included in the study to obtain a power of $81 \%$ with a significance level of 0.05. All of them were included in the final statistical analysis, as shown in the flowchart (Figure 1).

\section{Biochemical analyses}

Peripheral blood samples were collected for determination of $25(\mathrm{OH}) \mathrm{D}$, iron, ferritin, haemoglobin, C-reactive protein (CRP), white and red blood cell and platelet counts. Quantitative determination of $25(\mathrm{OH}) \mathrm{D}$ was carried out by using ARCHITECT 25-OH vitamin D chemiluminescent immunoassay (Abbott Ireland, Diagnostics Division, Ireland). The levels of $25(\mathrm{OH}) \mathrm{D} \geq 50 \mathrm{nmol} / \mathrm{L}$ were categorized as sufficient $30-50 \mathrm{nmol} / \mathrm{L}$ as insufficient, and $<30 \mathrm{nmol} / \mathrm{L}$ as deficient (12). There appears to be a lot of uncertainty about what 
$25(\mathrm{OH}) \mathrm{D}$ levels are sufficient and optimal, but there is a general consensus that optimal levels for health benefits are $\geq 70 \mathrm{nmol} / \mathrm{L}$. These optimal values we took into consideration only in the Discussion section. The $25(\mathrm{OH}) \mathrm{D}$ levels $\geq 125 \mathrm{nmol} / \mathrm{L}$ were categorized as excessive with possible harmful effect (12).

\section{Fatigue measurement}

Fatigue in the last two months was measured using the Pediatric Quality of Life Inventory ${ }^{\mathrm{TM}}$ (PedsQ $\mathrm{L}^{\mathrm{TM}}$ ) Multidimensional Fatigue Scale for young adults (age 18-25) (Copyright@ 1998 JW Varni, Ph.D.; all rights reserved; PedsQL ${ }^{\text {TM }}$ contact information and permission to use: Mapi Research Trust, Lyon, France - Internet: https://eprovide.mapi-trust. org and www.pedsql.org/index.html) (13). It is composed of 18 items comprising 3 dimensions: general fatigue, sleep/ rest fatigue, and cognitive fatigue. The scoring ranges from 0 to 100. A higher score reflects a greater fatigue impact.

\section{Psychological distress measurement}

Psychological distress in the last two months was measured using the Clinical Outcomes in Routine Evaluation (COREOM). CORE-OM is a 34-item scale designed as a multi-theoretical and multi-diagnostic measure of general psychological distress $(14,15)$. Higher total raw scores (range 0-136) represent poorer overall functioning. Scores are presented as follows: 1-20 healthy, 21-33 low level of psychological distress, 34-50 mild, 51-67 moderate, 68-84 moderate to severe, and $85+$ severe psychological distress.

\section{Headache severity measurement}

Headache severity was measured using the Migraine Disability Assessment (MIDAS) test. It is a short, self-administered questionnaire designed to quantify headache-related disability (16). Scores are presented as follows: 0-5 little or no disability, 6-10 mild disability, 11-20 moderate disability, and $21+$ severe disability.

\section{Nutrition and physical activity survey}

Information on the vitamin D rich food consumption, exposure to sunlight, and type and duration of physical activities during the last two months was obtained with a self-reporting survey. International Units (IU) for certain vitamin D source are set approximately and according to the relevant references (17-20). IU for vitamin D produced subcutaneously from sunlight exposure is set approximately and according to the relevant reference with similar geographical latitude (Boston: 42²1'30.35”N; Rijeka: 45²0'35.02"N) (21).

\section{Data analysis}

Data were analysed using the Statistica, Version 13.3 software. Demographic data were expressed as median and range (e.g., age, 25(OH)D serum level, etc.), and as total number (e.g., gender, number of Fitzpatrick skin type, insufficient/deficient student, etc.) (Table 1). To compare insufficient/deficient and sufficient group of students, and furthermore, students who practised cardio exercise $\geq 3.5$

\section{TABLE 1. Characteristics of study subjects}

\begin{tabular}{|c|c|c|}
\hline Variable & $\begin{array}{l}\text { Vitamin D insufficient } \\
\text { /deficient }\end{array}$ & Vitamin D sufficient \\
\hline $\begin{array}{l}25(\mathrm{OH}) \mathrm{D}(\mathrm{nmol} / \mathrm{L}) \text {, } \\
\text { median (range) }\end{array}$ & $36.8(26.8-49.0)$ & $62.2(55.4-108.3)$ \\
\hline n (\%) & $22(49 \%)$ & $23(51 \%)$ \\
\hline $\begin{array}{l}\text { Age (yrs), } \\
\text { median (range) }\end{array}$ & $21(20-24)$ & $21(20-23)$ \\
\hline Gender (n), M/F & $9 / 13$ & $5 / 18$ \\
\hline $\begin{array}{l}\mathrm{BMI}\left(\mathrm{kg} / \mathrm{m}^{2}\right) \text {, } \\
\text { median (range) }\end{array}$ & $22(18-24)$ & $22(18-24)$ \\
\hline $\begin{array}{l}\text { Fitzpatrick skin type II, } \\
\text { n (\%) }\end{array}$ & $1(4 \%)$ & $0(0 \%)$ \\
\hline $\begin{array}{l}\text { Fitzpatrick skin type III, } \\
\text { n (\%) }\end{array}$ & $16(73 \%)$ & $21(91 \%)$ \\
\hline $\begin{array}{l}\text { Fitzpatrick skin type IV, } \\
\text { n (\%) }\end{array}$ & $5(23 \%)$ & $2(9 \%)$ \\
\hline $\begin{array}{l}\text { Living apart from } \\
\text { parents, } \mathrm{n}(\%)\end{array}$ & $10(45 \%)$ & $11(48 \%)$ \\
\hline $\begin{array}{l}\text { Physical activity } \\
(\text { h/wk) }\end{array}$ & Students $(n=45)$ & \\
\hline $\begin{array}{l}\text { Light walking, } \\
\text { median (range) }\end{array}$ & $1.3(0.0-30.0)$ & \\
\hline $\begin{array}{l}\text { Cardio exercise } \\
\text { (running, aerobic, } \\
\text { Orbitrek, bike) }\end{array}$ & $3.5(0.0-8.0)$ & \\
\hline Strength exercise & $1.5(0.0-5.0)$ & \\
\hline $\begin{array}{l}\text { Outdoor exercise } \\
\text { (with sun exposure) }\end{array}$ & $0.0(0.0-2.5)$ & \\
\hline Overall sun exposure & $0.8(0.0-69.0)$ & \\
\hline
\end{tabular}

25(OH)D, 25-hydroxyvitamin D; BMI, body mass index; F, female; $M$, male; Fitzpatrick skin type III darker white skin that burns and tans; h/wk, hours/ week; sun exposure of neck, face, hands and arms in September and October (2-5 p.m.) in North Mediterranean Croatia for Fitzpatrick skin type III.

hours per week (h/wk) with those who practised less or no cardio exercise, Mann-Whitney $\mathrm{U}$ test for independent variables was used (Tables 2-4). For analysis of headache frequency during the past two months, we used Fisher exact test (Tables 2 and 4). We further report the Pearson correlation coefficient ( $r$ ) for the associations of 25(OH)D serum levels, psychological distress, headache severity, fatigue, amount of IU for vitamin D taken by vitamin D rich food and synthesized subcutaneously by sunlight exposure, and type 
TABLE 2. Fatigue (general, sleep/rest, cognitive and total), MIDAS, CORE-OM and headache frequency measures in vitamin D sufficient and insufficient/deficient students in the last 2 months

\begin{tabular}{|c|c|c|c|}
\hline & Group & & \\
\hline Questionnaire & $\begin{array}{l}\text { Vitamin D insufficient } \\
\text { /deficient }(n=22)\end{array}$ & $\begin{array}{l}\text { Vitamin D sufficient } \\
(n=23)\end{array}$ & \\
\hline PedsQL Fatigue (0-100) & Median (range) & Median (range) & $p$ values ${ }^{\mathrm{a}, \mathrm{b}}$ \\
\hline General Fatigue & $75.0(50.0-91.8)$ & $83.3(58.3-100.0)$ & 0.138 \\
\hline Sleep/Rest Fatigue & $54.8(33.3-87.5)$ & $79.2(37.5-95.8)$ & $0.035^{*}$ \\
\hline Cognitive Fatigue & $83.3(62.5-100)$. & $91.7(66.7-100.0)$ & 0.568 \\
\hline Total Fatigue & $73.6(48.6-93.1)$ & $83.6(63.9-93.1)$ & 0.074 \\
\hline MIDAS score $(0-21+)$ & $4(0-7)$ & $0(0-2)$ & $0.035^{*}$ \\
\hline Students with headaches, N (\%) & $12(55 \%)$ & $5(22 \%)$ & $0.024^{* b}$ \\
\hline CORE-OM (0-136) & $20(1-60)$ & $11(1-37)$ & 0.058 \\
\hline Normal psychological distress (1 - 20), N & 11 & 19 & / \\
\hline Low level of psychological distress $(21-33), \mathrm{N}$ & 5 & 2 & / \\
\hline Mild psychological distress $(34-50), \mathrm{N}$ & 3 & 2 & / \\
\hline Moderate psychological distress (51 - 67), N & 3 & 0 & / \\
\hline
\end{tabular}

TABLE 3. The amount of vitamin D IU consumed through vitamin D rich food and synthesised subcutaneously per month

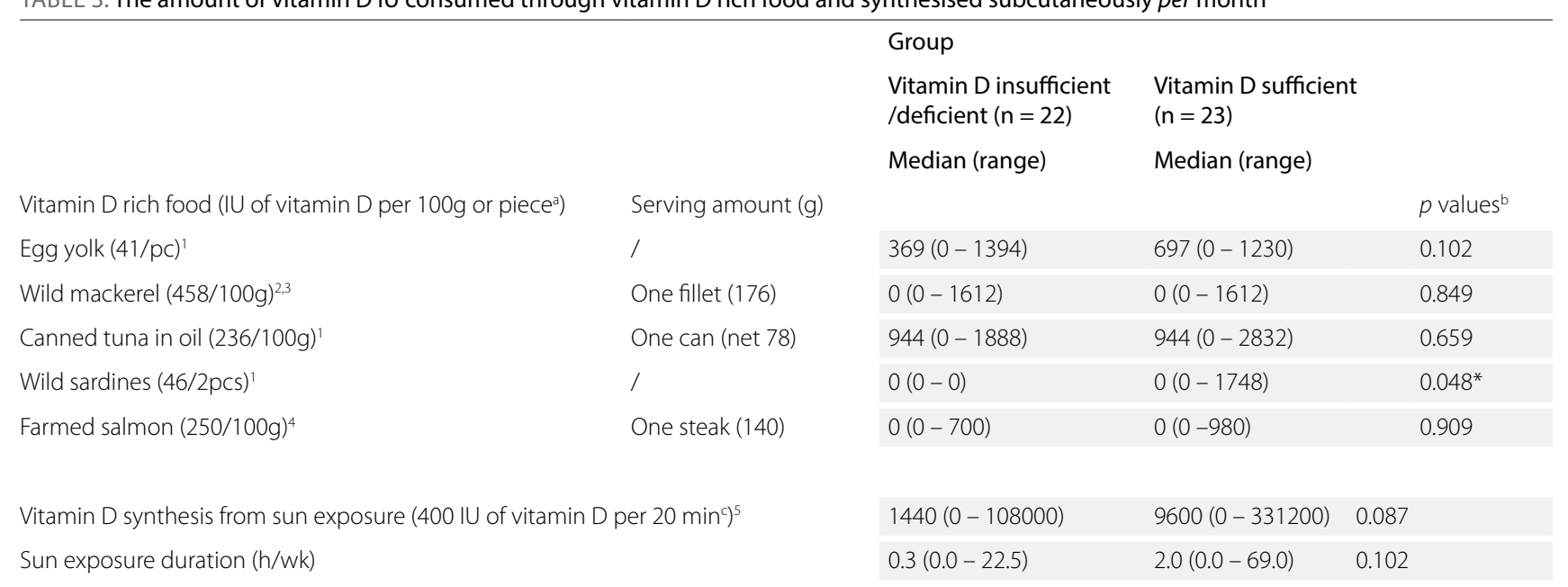

${ }^{a}$ Mann-Whitney $U$ test; ${ }^{b}$ Fisher exact test; ${ }^{*} \mathrm{p}<0.05$ is significant; $h$, hours;

$\mathrm{IU}$ values for certain vitamin D source are set approximately and according to the relevant references; ${ }^{b}$ Mann-Whitney $U$ test for calculated amounts of vitamin D IU with one serving; ${ }^{*} p<0.05$ is significant; ${ }^{`} I U$ value for vitamin D produced subcutaneously from sun exposure is set approximately and according to the relevant reference with similar geographical latitude; pc, piece; pcs, pieces; h/wk, hours per week; sun exposure of neck, face, hands and arms in September and October (2-5 p.m.) in north Mediterranean Croatia for Fitzpatrick skin type III darker white skin that burns and tans

'https://ods.od.nih.gov/factsheets/VitaminD-HealthProfessional/; ${ }^{2}$ https://www.canada.ca/en/health-canada/services/food-nutrition/healthy-eating/nutrient-data.html:

${ }^{3}$ https://www.eatthismuch.com/food/nutrition/mackerel,3303/;

${ }^{4}$ Lu Z, Chen TC, Zhang A, Persons KS, Kohn N, Berkowitz R, et al. An evaluation of the vitamin D3 content in fish: is the vitamin D content adequate to satisfy the dietary requirement for vitamin D? J Steroid Biochem Mol Biol. 2007;103:642-4;

${ }^{5}$ Terushkin V, Bender A, Psaty EL, Engelsen O, Wang SQ, Halpern AC. Estimated equivalency of vitamin D production from natural sun exposure versus oral vitamin D supplementation across seasons at two US latitudes. J Am Acad Dermatol. 2010;62:929.e1-9.

of exercise. A nominal significance level of 0.05 was used in all testing.

\section{RESULTS}

Sixty-two students were selected for this study, but only 45 were included in the final analysis according to the flow- chart (Figure 1). After analysing participant blood tests, we divided them into two groups according to the sufficient or deficient levels of 25(OH)D. There were no significant differences in the number of participants per group, median age, BMI value, gender, sunscreen usage no type of skin according to the Fitzpatrick scale. 


\begin{tabular}{|c|c|c|c|}
\hline \multirow[b]{2}{*}{ Questionnaire } & \multicolumn{3}{|l|}{ Group } \\
\hline & $\begin{array}{l}\text { Weekly cardio exercise } \\
\geq 3.5 \mathrm{~h}(\mathrm{~N}=25)\end{array}$ & $\begin{array}{l}\text { Weekly cardio exercise } \\
<3.5 \mathrm{~h}(\mathrm{~N}=20)\end{array}$ & \\
\hline PedsQL Fatigue (0-100) & Median (range) & Median (range) & $p$ values ${ }^{\mathrm{a}, \mathrm{b}}$ \\
\hline General Fatigue & $87.5(58.3-100.0)$ & $75.0(50.0-100.0)$ & $0.110^{\mathrm{a}}$ \\
\hline Sleep/Rest Fatigue & $83.8(54.8-95.8)$ & $54.2(33.3-79.2)$ & $0.004^{* a}$ \\
\hline Cognitive Fatigue & $91.7(66.7-100.0)$ & $87.5(62.5-100.0)$ & $0.909^{\mathrm{a}}$ \\
\hline Total Fatigue & $83.3(63.9-93.1)$ & $73.6(48.6-93.1)$ & $0.036^{* a}$ \\
\hline MIDAS score (0-21+) & $0(0-1)$ & $0(0-7)$ & $0.016^{* a}$ \\
\hline Students with headaches, N (\%) & $6(24 \%)$ & $11(55 \%)$ & $0.034^{* b}$ \\
\hline CORE-OM (0-136) & $11(1-37)$ & $20(1-60)$ & $0.036^{* a}$ \\
\hline Normal psychological distress $(1-20), \mathrm{N}$ & 21 & 9 & / \\
\hline Low level of psychological distress $(21-33), \mathrm{N}$ & 3 & 4 & / \\
\hline Mild psychological distress $(34-50), \mathrm{N}$ & 1 & 4 & / \\
\hline Moderate psychological distress $(51-67), \mathrm{N}$ & 0 & 3 & / \\
\hline
\end{tabular}

CORE-OM, Clinical Outcomes in Routine Evaluation; MIDAS, Migraine Disability Assessment

In all 45 participants, the median age was 21 (20-24) years with $69 \%$ of females; $49 \%$ of all students had $25(\mathrm{OH}) \mathrm{D}$ insufficiency/deficiency with a median of 36.8 (26.8-49.0). Only two of 45 (4\%) students had optimal levels (70-125 nmol/L) of $25(\mathrm{OH}) \mathrm{D}$ in the blood (data not shown) and four of them had blood 25(OH)D level below $30 \mathrm{nmol} / \mathrm{L}$ or were deficient. The main characteristics are shown in Table 1.

Higher levels of psychological distress (CORE-OM), headache frequency and severity (MIDAS), and fatigue (PedsQL) were recorded in all student categories with 25(OH)D insufficiency/deficiency, but a significant difference was found only in fatigue associated with sleep/rest ( $p=0.035)$, a number of students having headaches ( $n=12 / 22$ in vitamin $D$ insufficient/deficient group and $n=5 / 23$ in vitamin $D$ sufficient group; $p=0.024)$ and headache severity $(p=0.035)$ in the last two months (Table 2). In addition, CORE-OM ( $r=-$ 0.50, $p=0.024)$, general $(r=0.46, p=0.040)$ and sleep/rest $(r=0.46, p=0.039)$ categories of fatigue and total fatigue $(r=0.51, p=0.023)$ were associated with $25(\mathrm{OH}) \mathrm{D}$ levels (Table 5).

Students having cardio exercise $\geq 3.5 \mathrm{~h} / \mathrm{wk}(\mathrm{n}=25)$ had significantly lower levels of psychological distress $(p=0.036)$, headache severity $(p=0.016)$, sleep/rest and total fatigue $(p=0.004 ; p=0.036)$ besides general $(p=0.110)$ and cognitive fatigue ( $p=0.909$ ), as compared to those having less or no cardio exercise $(n=20)$ (Table 4). Six of $25(24 \%)$ students had a headache in the group with more cardio exercise in the last two months as compared to those with less cardio exercise (11 of 20; 55\%), yielding a significant difference $(p=0.024)$ (Table 4).
Vitamin D IU was calculated only for vitamin D rich food included on the survey food list, which students stated they had consumed. These data revealed similarity in consumption of vitamin D rich food between $25(\mathrm{OH}) \mathrm{D}$ insufficient/ deficient and sufficient group of students, except for consumption of wild sardines (not farmed or canned). Namely, data showed that students having sufficient blood 25(OH)D consumed more sardines and thus higher vitamin D IU intake ( $p=0.048$ ). In addition, data showed an association between the consumption of wild sardines and $25(\mathrm{OH}) \mathrm{D}$ blood levels ( $r=0.59, p=0.006$ ). Furthermore, students with sufficient blood $25(\mathrm{OH}) \mathrm{D}$ spent more time in the Sun, but with no significant difference ( $p=0.102)$ from students with insufficient/deficient 25(OH)D levels (Table 3).

\section{DISCUSSION}

With this preliminary pilot study, we wanted to explore vitamin D status and physical activity in young people, particularly younger students (18-24 years), having to deal with a higher level of study-related psychological distress, fatigue and headache. Furthermore, we wanted to explore the possible association between these three disorders and consumption of vitamin D rich food, Sun exposure and the type of physical activity they practised in the last two months (September and October).

Although this study included a small number of participants, the results showed similarity with a wide range of previous studies, which already presented this problem on vitamin D insufficiency/deficiency in several European countries, USA and Canada (3). The main difference from 
TABLE 5. Pearson correlations ( $r$ ) for CORE-OM, MIDAS, fatigue, serum 25(OH)D, type of exercise, sun exposure and consumption of vitamin D rich food

\begin{tabular}{|c|c|c|c|c|c|c|c|}
\hline \multirow[b]{2}{*}{ Variable } & & \multicolumn{5}{|c|}{ Physical activity and sun exposure (h/month), $\mathrm{N}=45$} & \multirow{2}{*}{$\begin{array}{l}\text { Vitamin D in blood } \\
25(\mathrm{OH}) \mathrm{D}(\mathrm{nmol} / \mathrm{L})\end{array}$} \\
\hline & & $\begin{array}{l}\text { Cardio } \\
\text { exercise }\end{array}$ & $\begin{array}{l}\text { Strength } \\
\text { exercise }\end{array}$ & $\begin{array}{l}\text { Light } \\
\text { walking }\end{array}$ & $\begin{array}{l}\text { Outdoor } \\
\text { exercise }\end{array}$ & $\begin{array}{l}\text { General sun } \\
\text { exposure }\end{array}$ & \\
\hline \multirow[t]{7}{*}{ Questionnaire } & CORE-OM & $-0.43^{*}$ & 0.11 & -0.23 & 0.03 & 0.10 & $-0.50^{*}$ \\
\hline & MIDAS & $-0.48^{*}$ & -0.09 & -0.37 & 0.09 & 0.08 & -0.33 \\
\hline & PedsQL - Multidimensional Fatigue & & & & & & \\
\hline & General Fatigue & 0.27 & 0.11 & 0.24 & 0.28 & 0.39 & $0.46^{*}$ \\
\hline & Sleep/Rest Fatigue & $0.44^{*}$ & 0.04 & 0.04 & 0.24 & 0.10 & $0.46^{*}$ \\
\hline & Cognitive Fatigue & -0.06 & 0.04 & -0.05 & 0.13 & 0.22 & 0.21 \\
\hline & Total Fatigue & 0.29 & 0.08 & 0.07 & 0.31 & 0.28 & $0.51^{*}$ \\
\hline Vitamin D in blood & $25(\mathrm{OH}) \mathrm{D}(\mathrm{nmol} / \mathrm{L})$ & 0.22 & -0.07 & -0.24 & -0.08 & 0.16 & / \\
\hline \multirow{5}{*}{$\begin{array}{l}\text { Vitamin D rich food (IU/ } \\
\text { month) }\end{array}$} & Egg yolk & / & & & & & 0.30 \\
\hline & Wild mackerel & / & & & & & 0.35 \\
\hline & Canned tuna in oil & / & & & & & 0.09 \\
\hline & Wild sardines & / & & & & & $0.59 *$ \\
\hline & Farmed salmon & / & & & & & 0.15 \\
\hline
\end{tabular}

CORE-OM, Clinical Outcomes in Routine Evaluation; MIDAS, Migraine Disability Assessment;

a Mann-Whitney $U$ test; bFisher exact test; ${ }^{*} \mathrm{p}<0.05$ is significant; $h$, hours; ${ }^{*}$ statistical significance at $p<0.05 ; 25(\mathrm{OH}) \mathrm{D}, 25$-hydroxyvitamin $\mathrm{D}$

our study is that all these studies analysed vitamin D status in groups of adolescents (12-18 years).

Our study results showed that 49\% (22 of 45) of students had insufficient/deficient blood levels of $25(\mathrm{OH}) \mathrm{D}$ (lower than $50 \mathrm{nmol} / \mathrm{L}$ ), suggesting that most students had inadequate direct sunlight exposure (median 0.8, range 0.0-69.0), although they live in a sunny part of Europe. If students were exposed to direct sunlight during the summer months from June till the end of August, they would have subsequently synthesised vitamin D subcutaneously and blood levels of $25(\mathrm{OH}) \mathrm{D}$ would have been higher in most of them $(21,22)$. Nutrition is another important source of vitamin D that could prevent insufficiency/deficiency and concomitant symptoms. However, our study results showed that the main food source of vitamin D that students had consumed were eggs and can tuna fish, and those few $(n=4)$ who consumed sardines had the highest vitamin D intake.

Insufficient levels of vitamin D in depressive patients have been confirmed by many authors, but there are conflicting results in subjects with anxiety disorders (23). The results of our study showed an association between 25(OH)D insufficiency and a higher level of psychological distress, although it was mostly within the normal range of CORE-OM values (score 1-20). However, in this group of students, mild to moderate psychological distress was also present, unlike the group of students with sufficient $25(\mathrm{OH}) \mathrm{D}$ blood levels.

Vitamin $D$ is involved in many brain physiological processes (24), and a new hypothesis suggests that vitamin D may in- teract with aggregates of the extracellular matrix (ECM), perineuronal nets (PNNs), to regulate brain plasticity. Dysregulation of PNNs caused by vitamin D insufficiency/deficiency may contribute to the presence of cognitive deficits, depression, anxiety, fatigue, and other neuropsychological conditions (25). In our study, students with 25(OH)D insufficiency also had a higher level of fatigue, although only fatigue associated with sleep and rest was significantly higher, unlike the group of students having sufficient $25(\mathrm{OH}) \mathrm{D}$ levels ( $p=0.035)$. In addition, all categories of fatigue (general, sleep/rest and total) correlated with $25(\mathrm{OH}) \mathrm{D}$ blood levels (Table 5) in general, besides cognitive fatigue. Vitamin D deficiency has been frequently associated with fatigue in uncontrolled trials. Nowak et al. showed that cholecalciferol given per os is efficient in treating fatigue in otherwise healthy persons with low serum 25(OH)D levels (4).

The exact pathophysiological association between vitamin D insufficiency/deficiency and headaches has not yet been fully elucidated. Probably, the factors that can resolve psychological stress could reduce the intensity or frequency of headaches too (26). Nearly all headaches experienced by college students are tension-type headaches due to chemical and neuronal imbalances in the brain caused by stress (including the stress caused by being overly anxious), which may be related to muscle tightening in the back of the neck and/or scalp $(27,28)$. Furthermore, vitamin D deficiency can lead to selective alterations in target innervation, resulting in presumptive nociceptor hyperinnervation of skeletal muscle, which in turn is likely to contribute to muscular hy- 
persensitivity and headaches (29). In our study, students with $25(\mathrm{OH}) \mathrm{D}$ insufficiency/deficiency had a significantly $(p=0.024)$ higher headache frequency (12 of 22), unlike students with sufficient 25(OH)D (5 from 23) levels. Although we found a significant difference in MIDAS values between $25(\mathrm{OH}) \mathrm{D}$ insufficient/deficient and 25(OH)D sufficient groups of students, MIDAS values were not in correlation with $25(\mathrm{OH}) \mathrm{D}$ blood values in general. To find the possible correlation it is undoubtedly needed to repeat this study on a larger number of participants. In addition, a limitation of this study was that we did not examine the specific type of headache.

On the contrary, physical activity, specifically the cardio type of exercise, was in correlation with headaches, psychological distress and fatigue related to sleep/rest (Table 5). Students who practised more cardio exercise had less frequent headaches, lower levels of psychological distress, and needed less sleep or rest because of fatigue (Table 1). We noticed that those students having cardio exercise $\geq 3.5 \mathrm{~h} / \mathrm{wk}$ had lower levels of psychological distress, headache severity and fatigue. Comparison of students having cardio exercise $\geq 3.5 \mathrm{~h} / \mathrm{wk}$ and those having less or no cardio exercise showed significant difference (Table 4). Psychological distress also was at lower levels in the former, however, mostly in the normal range (score 1-20), with a lower number of those having mild to moderate distress, unlike the $25(\mathrm{OH}) \mathrm{D}$ insufficient/deficient group (Table 4). These findings are supported by a previous study conducted in undergraduate university population in the United Kingdom, where the authors observed significant differences between the low, medium and high exercise groups on the mental health scales, indicating better mental health for those engaged in more exercise (8).

Cardio exercise such as running and aerobic affects the brain in many ways; pumps more oxygen to the brain (30), promotes brain plasticity, increases the release of body hormones and growth factors in the brain for new neuronal connections (30), which all together contribute to downregulation of psychological distress. In other words, exercise-induced stress is 'good stress' and alleviates 'bad stress' that causes depression, anxiety symptoms $(30,31)$, and furthermore fatigue and headaches as well $(10,32,33)$.

From our preliminary pilot study, we can conclude that vitamin D and physical activity, especially cardio type of exercise, is associated with better psychological functioning, and thus probably with better quality of life with a lower level of fatigue and headaches in undergraduate students who have to deal with a higher level of stress. Dietary habits that involve vitamin D rich food consumption are important to compensate for a decrease in serum 25(OH)D levels due to lower sunlight exposure. However, this may not be enough and should be supported by vitamin D supplemen- tation. To confirm these findings, further randomized controlled studies on a larger group of different undergraduate students are required.

\section{REFERENCES}

1. Wardle J, Steptoe A, Gulis G, et al. Depression, perceived control, and life satisfaction in university students from Central-Eastern and Western Europe. Int J Behav Med. 2004;11:27-36. doi: 10.1207/s15327558ijbm1101_4

2. Inman AG, Ladany N, Constantine MG, Morano CK. Development and preliminary validation of the Cultural Values Conflict Scale for South Asian women. J Couns Psychol. 2001;48:17-27. doi.org/10.1037/0022-0167.48.1.17

3. González-Gross M, Valtueña J, Breidenassel C, et al. Vitamin D status among adolescents in Europe: the Healthy Lifestyle in Europe by Nutrition in Adolescence study. Br J Nutr. 2012;107:755-64. doi: 10.1017/S0007114511003527

4. Nowak A, Boesch L, Andres E, et al. Effect of vitamin D3 on self-perceived fatigue: a double-blind randomized placebo-controlled trial. Medicine (Baltimore). 2016;95:e5353. doi: 10.1097/MD.0000000000005353

5. Bahrami A, Mazloum SR, Maghsoudi S, et al. High dose vitamin D supplementation is associated with a reduction in depression score among adolescent girls: a nine-week follow-up study. J Diet Suppl. 2018;15:173-82. doi: 10.1080/19390211.2017.1334736

6. Prakash S, Rathore C, Makwana P, Dave A, Joshi H, Parekh H. Vitamin D deficiency in patients with chronic tension-type headache: a case-control study. Headache. 2017;57:1096-108. doi: 10.1111/head.13096

7. Song TJ, Chu MK, Sohn JH, Ahn HY, Lee SH, Cho SJ. Effect of Vitamin D deficiency on the frequency of headaches in migraine. J Clin Neurol. 2018;14:366-73. doi: 10.3988/jcn.2018.14.3.366

8. Tyson P, Wilson K, Crone D, Brailsford R, Laws K. Physical activity and mental health in a student population. J Ment Health. 2010;19:492-9. doi: 10.3109/09638230902968308

9. de Vries JD, van Hooff ML, Geurts SA, Kompier MA. Exercise as an intervention to reduce study-related fatigue among university students: a two-arm parallel randomized controlled trial. PLoS One. 2016;11:e0152137. doi: 10.1371/journal.pone.0152137

10. Amin FM, Aristeidou S, Baraldi C, et al. The association between migraine and physical exercise. J Headache Pain. 2018;19:83. doi: 10.1186/s10194-018-0902-y

11. Fitzpatrick TB. The validity and practicality of sun-reactive skin types I through VI. Arch Dermatol. 1988;124:869-71. doi: 10.1001/archderm.124.6.869

12. Sahota O. Understanding vitamin D deficiency. Age Ageing. 2014;43:589-91. doi: 10.1093/ageing/afu104

13. Varni JW, Limbers CA. The PedsQL ${ }^{\mathrm{Tm}}$ Multidimensional Fatigue Scale in young adults: feasibility, reliability and validity in a university student population. Qual Life Res. 2008;17:105-14. doi: 10.1007/s11136-007-9282-5

14. Evans C, Connell J, Barkham M, et al. Towards a standardised brief outcome measure: psychometric properties and utility of the CORE-OM. Br J Psychiatry. 2002;180:51-60. doi: 10.1192/bjp.180.1.51

15. Jokić-Begić N, Lauri Korajlija A, Jurin T. Factor structure, psychometric properties and cut-off scores of Croatian version of Clinical Outcomes in Routines Evaluation-Outcome Measure (CORE-OM). Psihologijske teme. 2014;23:265-88.

16. Zandifar A, Asgari F, Haghdoost F, et al. Reliability and validity of the migraine disability assessment scale among migraine and tension type headache in Iranian patients. Biomed Res Int. 2014;2014:978064. doi: 10.1155/2014/978064

17. VitaminD-HealthProfessional. https://ods.od.nih.gov/factsheets/ VitaminD-HealthProfessional/. Accessed July 2019. 
18. food-nutrition/healthy-eating. https://www.canada.ca/en/health-canada/services/food-nutrition/healthy-eating/nutrient-data.html. Accessed June 2018.

19. food/nutrition. https://www.eatthismuch.com/food/nutrition/ mackerel,3303/. Accessed June 2018.

20. Lu Z, Chen TC, Zhang A, et al. An evaluation of the vitamin D3 content in fish: is the vitamin $D$ content adequate to satisfy the dietary requirement for vitamin D? J Steroid Biochem Mol Biol. 2007;103:642-4. doi: 10.1016/j.jsbmb.2006.12.010

21. Terushkin V, Bender A, Psaty EL, Engelsen O, Wang SQ, Halpern AC. Estimated equivalency of vitamin $D$ production from natural sun exposure versus oral vitamin D supplementation across seasons at two US latitudes. J Am Acad Dermatol. 2010;62:929.e1-9. doi: 10.1016/j.jaad.2009.07.028

22. Kift R, Lesley E, Rhodes, Farrar MD, Webb AR. Is sunlight exposure enough to avoid wintertime vitamin $D$ deficiency in United Kingdom population groups? Int J Environ Res Public Health. 2018;15:1624. doi: 10.3390/ijerph15081624

23. Bičíková M, Dušková $\mathrm{M}$, Vítků J, et al. Vitamin D in anxiety and affective disorders. Physiol Res. 2015;64:S101-3. doi: 10.33549/physiolres.933082

24. Cuomo A, Maina G, Bolognesi S, et al. Prevalence and correlates of vitamin D deficiency in a sample of 290 inpatients with mental illness. Front Psychiatry. 2019;10:167. doi: 10.3389/fpsyt.2019.00167

25. Mayne PE, Burne THJ. Vitamin D in synaptic plasticity, cognitive function, and neuropsychiatric illness. Trends Neurosci. 2019;42:293-306. doi: 10.1016/j.tins.2019.01.003

26. Thorn BE, Pence LB, Ward LC, et al. A randomized clinical trial of targeted cognitive behavioral treatment to reduce catastrophizing in chronic headache sufferers. J Pain. 2007;8:938-49. doi: 10.1016/j.jpain.2007.06.010
27. causes-of-headaches (2009). https://headaches.org/2009/10/08/ causes-of-headaches-in-college-students/. Accesssed July 2019

28. Virtanen JK, Giniatullin R, Mäntyselkä P, et al. Low serum 25-hydroxyvitamin $D$ is associated with higher risk of frequent headache in middle-aged and older men. Sci Rep. 217;7:39697. doi: 10.1038/srep39697

29. Tague SE, Clarke GL, Winter MK, McCarson KE, Wright DE, Smith PG. Vitamin $D$ deficiency promotes skeletal muscle hypersensitivity and sensory hyperinnervation. J Neurosci. 2011;31:13728-38. doi: 10.1523/JNEUROSCI.3637-11.2011

30. Heijnen S, Hommel B, Kibele A, Colzato LS. Neuromodulation of aerobic exercise - a review. Front Psychol. 2016;6:1890. doi: 10.3389/fpsyg.2015.01890

31. Wang L, Li J, Bai S, et al. The effect of different exercise on anxiety and depression of college students. Cite as: AIP Conference Proceedings. 2019;2079:020033. doi: 10.1063/1.5092411

32. Grubić Kezele T, Babić M, Štimac D. Exploring the feasibility of a mild and short 4-week combined upper limb and breathing exercise program as a possible home base program to decrease fatigue and improve quality of life in ambulatory and non-ambulatory multiple sclerosis individuals. Neurol Sci. 2019;40:733-43. doi: 10.1007/s10072-019-3707-0

33. Grubić Kezele T, Babić M, Kauzlarić-Živković T, Gulić T. Combined upper limb and breathing exercise programme for pain management in ambulatory and non-ambulatory multiple sclerosis individuals: part II analyses from feasibility study. Neurol Sci. Published online 17 August, 2019. https://doi.org/10.1007/s10072-019-04046-4. doi: 10.1007/s10072-019-04046-4_

\section{Povezanost insuficijencije vitamina D i niske tjelesne aktivnosti s umorom, glavoboljom i psihološkim problemima kod studenata, Sjevernomediteranska Hrvatska - pilot istraživanje}

Tatjana Kehler, Tanja Grubić Kezele, Ariana Fužinac-Smojver, Tamara Kauzlarić-Živković

Cilj ove studije bio je ispitati vitamin D u serumu kod studenata prijediplomskog zdravstvenog studija i njegovu povezanost s učestalošću konzumacije hrane bogate vitaminom D, izlaganjem suncu, umorom vezanim za studiranje, glavoboljom i psihopatološkim statusom, te posljednja tri s vrstom tjelesne aktivnosti. Razina 25-hidroksivitamina D (25-OHD-a) u krvi, procjena nesposobnosti vezane za migrenu (Migraine Disability Assessment (MIDAS)), kakvoće života vezane za umor (Pediatric Quality of Life Inventory Multidimensional Fatigue Scale), psihopatološkog statusa (Clinical Outcomes in Routine Evaluation - Outcome Measure (COREOM)), načina prehrane i tjelesne aktivnosti ispitani su kod nasumice izabranih studenata. Rezultati studije su pokazali da je 49\% studenata imalo nedostatak/manjak 25-OHD-a. Vrijednosti MIDAS-a bile su veće u skupini s nedostatkom/manjkom ( $p=0.035)$ i bile su povezane su sa satima tjednih kardio-vježbi $(r=-0,48, p=0,031)$. CORE-OM i ukupni umor korelirali su s 25-OHD-a $(r=-0,59$, $p=0,024 ; r=0,51, p=0,023$ ). Studenti s dovoljno 25- OHD-a imali su značajno veći unos vitamina D konzumirajući srdele u svojoj mjesečnoj prehrani ( $p=0,048)$; 25 -OHD je korelirao s količinom mjesečno pojedenih srdela ( $r=0,59, p=0,006)$. Naši rezultati pružaju početne dokaze o tome kako je pravilan način života ispunjen pravilnom tjelesnom aktivnošću, posebno kardio-vježbanjem, i prehranom bogatom vitaminom D važan za smanjenje umora, glavobolje i psiholoških tegoba. 